\title{
A Mirror for Statesmen: Leonardo Bruni's History of the Florentine People
}

\section{Citation}

Hankins, James. A mirror for statesmen: Leonardo Bruni's history of the Florentine people. Unpublished paper, Harvard University.

\section{Permanent link}

http://nrs.harvard.edu/urn-3:HUL.InstRepos:2958221

\section{Terms of Use}

This article was downloaded from Harvard University's DASH repository, and is made available under the terms and conditions applicable to Other Posted Material, as set forth at http:// nrs.harvard.edu/urn-3:HUL.InstRepos:dash.current.terms-of-use\#LAA

\section{Share Your Story}

The Harvard community has made this article openly available.

Please share how this access benefits you. Submit a story.

Accessibility 


\author{
A MirRor FOR STATESMEN \\ LEONARdo BRUNI's HISTORY OF THE FLORENTINE PEOPLE*
}

\title{
JAMES HANKINS
}

Harvard University

It will perhaps seem odd to claim that Leonardo Bruni's History of the Florentine People has been neglected by students of Renaissance political thought. Written over the space of a quarter century, between 1415/16 and 1442, it was the civic humanist's most important original work. When the famous Florentine chancellor died in 1444 he was laid out at his public funeral on a bier clasping a copy of the History against his breast, a pose later preserved by Bernardo Rossellini in a portrait sculpture for the Bruni tomb in Santa Croce. ${ }^{1}$ The work was an official history, preserved in the chapel of the Palazzo Vecchio in Florence along with the Pandects of Justinian (captured at the conquest of Pisa in 1406), the banners of defeated foes, and other civic trophies. ${ }^{2}$ It survives in some sixty manuscripts and was translated into Italian by command of Bruni's employer, the Florentine Signoria; the translation, by Donato Acciaiuoli, was also widely circulated in manuscript and was printed a number of times in the fifteenth and sixteenth centuries. ${ }^{3}$ Then and now it was considered one of the greatest works of humanist historiography and was the model for an entire genre of city-state histories in the fifteenth and sixteenth centuries. ${ }^{4}$ 
Yet despite its obvious importance as a major monument of Renaissance civic humanism, the work has been neglected by historians of political thought. Surveys like Quentin Skinner's classic Foundations of modern political thought and his more recent collection Visions of politics, Antony Black's Political thought in Europe, the Cambridge history of political thought and its Italian equivalent, the multivolume Storia delle idee politiche, economiche e sociali, all tend to rely on a handful of shorter texts such as the Laudatio Florentinae urbis, the oration for the funeral of Nanni Strozzi, and the treatise On knighthood when characterizing Bruni's political thought. ${ }^{5}$ The History of Florence, on the other hand-when not dismissed as mere Livian pastiche confected from vernacular chronicles - has been studied for its historical methodology; for its place in the history of humanistic historiography; as a work revealing a republican ideology of liberty; as a work of imperialistic propaganda; as a rhetorical artifact; as a moment in the history of historical consciousness; and as a secular vision of historical development. ${ }^{6}$

While all these perspectives are interesting and useful, they miss one distinctive, indeed key trait of Bruni's pioneering history: its didacticism. Bruni's history is intended as a work of moral education. It is meant to teach Florentine and Tuscan political elites how to behave with virtue, how to preserve and extend the power of their respublica. It shows them which policies and laws worked in the past and which did not work, and why. Its didacticism is sustained and explicit throughout. It is far more explicitly pedagogical than either its main source, Giovanni and Matteo Villani's chronicle, or its chief model, Livy. Bruni instructs his audience both in summaries and asides addressed directly to the reader or in the form of speeches delivered by admirable Florentines. ${ }^{7}$ His didacticism is implicit as well, for Bruni certainly knew Aristotle's view, expressed in Rhetoric 1.9, that praise could be 
deployed as a form of moral counsel. The History of the Florentine People is on the surface a celebration of the city's accomplishments, but Bruni is always counseling while he is praising: urging modern Florentines to live up to the accomplishments of their ancestors and not to repeat their mistakes. ${ }^{8}$

It is the contention of this article that attending to what Bruni takes to be the great lessons of Florentine history greatly sharpens and in part corrects our picture of Bruni as a political thinker and therefore of the political thought of civic humanism in general. In particular, it should change our view of Bruni's relationship to the Aristotelian tradition and to Machiavelli. Bruni is usually described as an Aristotelian in his political theory, and this seems plausible on the face of it given the many years of labour Bruni devoted to the translation of Aristotle's Ethics and Politics as well as the pseudo-Aristotelian Economics, not to mention his own explicit statements that he was a follower of Aristotle. ${ }^{9}$ But study of the History shows us that in certain crucial respects Bruni rejected Aristotle's political ideals. For example, both Aristotle (Politics 7.2) and Plato (Laws 1.628b) criticise constitutions designed with a view to imperial expansion; both see such a constitution as disordered, as enshrining a mistaken preference for the active over the contemplative life, for the life of the emotions and honour over the life of reason and self-mastery. But Bruni's History passionately endorses the goal of glory and the acquisition of territory. For example, in a speech put into the mouth of Pino della Tosa, who is advocating before the Florentine Signoria the purchase of Lucca in 1329, Bruni writes:

And just think, too, how much your power will increase when you get control of this most beautiful and well-fortified city-state, with such a large territory and so many towns and citadels! Think how much the glory, fame and majesty of the Florentine People will grow if a city which has long been nearly our equal 
in wealth and power should be made subject to you! For my part, I confess, as one who practices the common life and moral customs of mankind, I am moved by the things that men hold to be goods: extending borders, enlarging empire, raising on high the glory and splendor of the state, assuring our own security and advantage. If we say that these are not desirable things, then the welfare of the republic, patriotism and practically this whole life of ours will be overthrown. If those who would dissuade you from taking Lucca despise such things and think them of no account, they are in their turn introducing new moral standards into life; if they approve of them and consider them goods, then they must necessarily believe that Lucca should be taken, for so many goods and advantages follow together therefrom $(6.5) .{ }^{10}$

There can be little doubt that this speech reflects Bruni's own views. He explicitly states, when Florence fails to take Pino's advice, that it was 'an extremely bad decision on the city's part'. And the speech occurs at the beginning of Book VI, which is mostly devoted to Florence's failed attempt to take control of Lucca. The rest of the book in effect shows the high cost of this bad decision: enormous expense, loss of life, shame, military failure, and in the end, the tyranny of Walter of Brienne, all result directly from this colossal error in political judgement.

Bruni's History also reveals a civic humanism far less concerned with promoting classical virtues in the service of the good life, as presented by GrecoRoman philosophers, and far more concerned with finding pragmatic solutions to pressing political and ethical problems threatening the welfare of the state. Bruni's central concern is with enabling a virtuous civil life so as to increase Florentine political and military strength. To some extent this means finding ways to inculcate classical virtues such as prudence, moderation, courage, love of country, and thrift. But Bruni's search for lessons in history takes him in new directions not explored by classical historians. Thucydides, Livy, Sallust, and Tacitus all obviously expect their 
readers to acquire prudence from study of the past, but they do not develop a theory of political success or failure; success or failure is typically seen in moral terms without remainder. Polybius of course does have a theory of Roman success, but when elaborating it he has, in effect, to stop his narrative (at the end of Book V) in order to launch into a synchronic, abstract analysis of the Roman constitution, religion and military customs in Book VI. Bruni's approach, by contrast, is both analytical and intrinsically historical; his explanations of Florentine success and failure both motivate and derive from the narrative. Prudence and imprudence are shown in action. A favourite maxim is that 'time and experience, the mistress of affairs' reveal the truth. So, for example, the longevity of the institution of the Priorate shows that it was good and well-designed (3.58-59). ${ }^{11}$ Outcomes are the judge of prudence. To be sure, Bruni does not dissent from the basic assumption of ancient ethics, that practice of the virtues is the key to happiness, both private and public. But his understanding of political happiness as consisting in the wealth, strength and imperialistic success of one's native city imports a Roman note alien to ancient Greek political theory. ${ }^{12}$ It issues in a strikingly different, proto-Machiavellian analysis of political virtue. For Bruni, virtue is already trending towards virtù.

Bruni's History gives his fellow-citizens counsel in four broad areas: diplomacy, the conduct of war, the design of laws and institutions, and the nature of vivere civile, i.e., the best forms of behaviour for citizens to practice. Although these are all interrelated, the present article will focus on his lessons about citizen behaviour and how such behaviour is supported, or not supported, by laws and institutions.

Like most modern historians of Florence, Bruni identifies factionalism as the main obstacle to Florence's success in the late medieval period. Factionalism had various causes. There were foreign ones, like the struggle between pope and empire; 
and domestic ones, such as rivalry between noble clans or class struggles between the nobility and the people. The term People or popolo has a precise meaning for Bruni, as it did for contemporaries, and signifies the broad middle ranks of society, excluding magnates or nobles on the one hand and the mob on the other. In the thirteenth century the middle stratum of society organized itself politically and formed a corporation for the purposes of self-protection, with its own statutes, offices, military organization, coats of arms, seals, and banners. From its earliest appearance in Florence it was aligned with the pro-papal Guelf Party against the Ghibellines. This well-defined corporate and ideological identity made Florence's middle classes quite unlike those of the ancient Greek city-states described by Aristotle. Again unlike Aristotle's middle class, members of the Popolo are not necessarily middling in economic means; as we shall see, the Popolo is distinguished from the magnate class primarily by its political culture. As the full title of the work suggests, The history of the Florentine People, the real hero of Bruni's history is the People of Florence - the People in this special, restricted sense.

Since the People in Florentine history act consistently to suppress the hereditary nobility, persecute Ghibellines, and to exclude the poor from political power, it is also in Aristotelian terms the name of a faction, a pars, by definition opposed to the good of the whole. Given Bruni's Aristotelian commitments, therefore, one might expect from him a cool and critical analysis of the Popolo's factional behaviour. But far from being a philosophical historian, above the fray, Bruni tells the story of the People as their partisan. Throughout the twelve books of the History he is an open partisan of the People against a lawless and unpatriotic nobility, against a passionate and dangerous mob, and against all Ghibellines. Bruni's partisanship is in aid of his larger goal, which is to encourage Florentines to put loyalty to their city 
above loyalty to faction, clan, class or Church. His belief is that the Popolo can and should provide a focus for civic loyalty.

Bruni's partisanship is evident in his treatment of factional struggles in Florence. He describes a number of attempts to bring social peace to Florence and assesses their effectiveness. In 1266, during the Guelf restoration following the battle of Benevento, the Florentines attempted to pacify the parties by forcing intermarriage between Guelf and Ghibelline clans. They believed the old legend that the GuelfGhibelline split had had its origins in a marriage dispute between the Buondelmonte and Amidei families, and reasoned that if a broken marriage had caused the problem, successful marriages would solve it - 'a remedy of opposites', as Bruni called it. In fact, 'the disease was too serious to be cured by such medicine', Bruni writes (2.110). The policy at the start offered hope but 'was soon revealed as a wasted effort'. It failed for two reasons. The inequality of power between Guelfs and Ghibellines meant that the strong and victorious party could not respect the defeated and weak one, so the weaker party was systematically in an inferior position in marriage negotiations. Each party regarded the other as traitors and enemies of the fatherland. Second, Ghibelline forces outside the city continued to threaten it, which generated suspicions within and made mutual trust between factions impossible.

Bruni also examines five attempts by the Church to make peace within the city, all of which fail. The peace of Gregory X (1273) failed because the pope, despite his holiness and good intentions, did not make a realistic assessment of the situation. He did not realize that memory could not be wiped out; he did not appreciate that partisans who had shown themselves wicked and deceitful in the past could not be trusted in the present; and he was mistaken in believing that intelligent citizens would not value their security above pious hopes for peace (3.24). Cardinal 
Latino's peace of $1279-80$, by contrast, showed more intelligence and understanding of the local situation. Latino was effective in persuading people that they would be more secure with both factions inside the city and designed institutions and legal procedures to protect both parties. He arranged formal reconciliations, marriages between factions, and even destroyed records of earlier partisan activities to wipe out the memory of mutual hatreds. His peace lasted a couple of years, but was ultimately undone by the Angevin disaster in the Sicilian Vespers of 1282. A fragile balance of parties inside the city could not survive a major shift in the balance of power outside it $(3.52,3.58)$. Similar pressures and suspicions destroyed three later papal attempts at pacification of the quarrels between Whites and Blacks in 1300, 1303, and 1306; the last two attempts, indeed, came apart owing to suspicions of the pope's own partisan agenda. In 1306 the papal peacemaker was not even admitted to the city on the grounds that the previous peacemakers had only made things worse (4.100). Bruni's conclusion is that whenever one party is stronger than another in the city which will be practically all the time - any solution aiming at the peaceful coexistence of factions is doomed to failure. The implication is that exiles are better left outside the city. Piety and good intentions cannot abolish history or geopolitics.

Idealistic attempts at abstract social justice also fail to solve problems arising from antagonism between social classes. Bruni teaches this lesson with particular clarity at the beginning of Book VII, while describing what happened after the expulsion of Walter of Brienne, the French tyrant who briefly dominated Florence in 1342-3. In gratitude for the meritorious actions of the nobility in freeing Florence from the tyrant, the civic leaders, led by their bishop, Angelo Acciaiuoli, understandably but unwisely reverse the half-century-long policy of excluding the nobility from public life and allowed them to hold magistracies. 
What was new, and of the greatest import to the republic, was their decision, against the example of earlier times, to accept the nobility into this and other magistracies of the republic. There were two principal reasons for this decision. One was concern for civic harmony. It was believed that the state would be tranquil and the spirits of its citizens quiet and peaceable if no part of the city were excluded from honours and thus driven to hate the present regime because of injustices to itself. The other reason was manifest merit, since the nobility had actively devoted its energies to expelling the tyrant. Their actions won still more approval in that the tyrant had granted many favors to their class, but they had preferred liberty and love of country to his acts of beneficence, which was a great proof of the sincerity of their public spirit. So for these reasons the nobility were allowed to share in the governance of the state (7.3).

But this innovation turned the ancient constitution (antiqua gubernandi forma) upside-down, and subverted the purposes of the old, anti-magnate ordinances.

The latter [ordinances] had been wisely framed in the beginning and afterwards preserved in the state with salutary effect. But at this time, the body politic had been entirely equalized and through concord made as one; so with the sources of contention having lapsed, the safeguards against contention lapsed as well (7.4).

The new situation in the abstract seemed just, but it was ineffective. 'Although [the reforming magistrates] seemed to have good reasons for designing the constitution as they did, it did not last very long' (7.6). The nobility soon began to be suspected of abuse of power, leading to unrest among the people. Envy and contention, 'the usual civic diseases', returned to the city, and the populares began to think they had exchanged one tyrant for many. Eventually verbal contention turned to violence and 
civil war. Tranquillity was restored only when the People reasserted its military dominance over the nobility and restored the popular regime, excluding the nobles (7.10-14). Once again, abstract principles of justice had been undone by political reality. The nobility, being naturally prone to arrogance and power-seeking, were bound to abuse public power to achieve their ends; and the People, being more powerful militarily, was bound to reassert itself. History and the realities of power trumped ideals of political equality.

Bruni's preferred solutions to the problems of partisanship and class struggle are institutional and moral. He praises the magistracy of the Priorate (3.59), in terms reminiscent of Aristotle, for empowering the middle classes against the nobility. Invoking his principle of the mean, Aristotle had written in Politics 4.11 that the middle class is the best class to rule because they are most likely to listen to reason. The upper classes are given to violence and great crimes, the lower classes to petty criminality, but the middle classes don't covet the goods of others. They know how to obey as well as command, unlike the other classes, and they are not consumed with ambition. They achieve what they want in a spirit of friendship, and a stable community depends on friendship; any good state aims at being as far as possible a society of equals and peers. Only in states with a large middle class, where there is rough equality of property, does the possibility of good government exist. Thus Aristotle.

Bruni's analysis at first sight appears to echo this general sentiment. Writing of the foundation of the Priorate in 1282, he remarks:

This form of administration was populist to the highest degree, as can be seen from its very name. Because there were certain powerful individuals who seemed inordinately given to civil discord, the government of the city was 
handed over to a quiet and peace-loving sort of person who was more inclined to carry on business in peacetime than to engage in war and strife. That is why they were called Priors of the Guilds: they enjoyed popular approval and preference because they were neither predatory nor seditious, but frugal and peace-loving persons, each exercising his own métier - for the lazy have to feed off the goods of others. (3.59).

But Bruni's emphasis here is not on the middling economic status of the magistrates indeed he points out that one of the first priors, Jacopo de' Bardi, was from a noble and extremely rich family - but on their moderate behavioural patterns. The distinction between magnate and popolano was for him (as for some modern historians of medieval Italy) a matter of political culture. ${ }^{13}$ Magnates were men who admired and emulated the military, bucolic and amatory ways of French chivalry, who rode horses in cavalcades through the city streets. They were given to violence and motivated principally by anti-social notions of personal honour. ${ }^{14}$ For them, honour trumped the common good; they would tear the city apart out of misplaced loyalty to pope or emperor or clan or party. They lived off rents and could devote themselves full-time to military and political pursuits. They had no respect for the laws of the city, made by and for the powerless, and preferred private revenge to the use of the courts. A good guildsman, by contrast, was somebody who devoted most of his efforts to his own business and not to his political ambitions; whose business interests made him prefer peace to war; whose experience in trade and commerce made him prudent and far-sighted. He could rule and be ruled in turn because he had other things to do with his time. Not being able to rely for protection on an ancient and powerful clan, he looked to the city and its laws to defend himself against his enemies, and therefore his first loyalty was to the city. He did not have a large 
clientele whose interests might compete with that of the city. It was obvious to Bruni that such a man would make a far better magistrate than a magnate.

This is not to say that Bruni wanted his guildsman-citizen to be unmilitary. To allow the very lowest classes to take up arms was a capital error, as the Ciompi tumult showed (9.1-10). But the Popolo, ideally, should bear arms. Like most republicans, Bruni believed an armed and vigilant citizenry was necessary to defend its own prerogatives against powerful forces inside and outside the city. He believed the practice of bearing arms required institutional support, which is why he approved of the institution of militia companies to protect the Popolo against the domination of the magnates. The liberty of the people required them to be organized militarily (2.99). There was hardly anything Bruni deplored more in Florentine history than the custom that began in 1351 of allowing citizens to purchase exemptions from military service. Bruni roundly condemns this practice in a passage that offers a good example of his didactic manner:

Many decisions were also taken that winter about raising funds for war. Among other blameworthy decisions, those with military obligations in Florentine territory were allowed exemption from military service if they paid money to the state for hiring foreign and outside soldiers. The only sure effect of this was to render the city's own population unwarlike, so that the citizens would look to others to defend their own fortunes, and would not know how to defend themselves or fight for their country. These and many similar mistakes of statecraft are committed by governors who lack experience, and though small in the beginning, such errors later give birth to massive harms (7.101).

In Bruni's later Constitution of the Florentines (1439), a treatise in Greek describing the Florentine constitution in the manner of Aristotle, he remarked that it was this 
decision that had led to the emergence of oligarchy in Florence, since the predominant use of mercenaries put power into the hands of those who paid for them. ${ }^{15}$

For Bruni, however, it was not enough that the People be able to defend their interests militarily; they also needed the support of the laws in their daily intercourse with the nobility. This is why he praises the institution of the Ordinances of Justice in 1293 and their sponsor, Giano della Bella, who is one of the great heroes of the History (4.26-40). Up to that time, says Bruni, the People had been in a relationship of 'honourable servitude' (honesta veluti servitute) with respect to the nobility (nobilitas). The nobility had never treated the People as an equal partner. As a result, the common people had suffered violence, arrogant contempt, seizure of goods, injustices of every kind, and had been unable to enforce the laws. The Ordinances remedied this situation by placing the nobility under heavy political and legal disabilities. They were stripped of political rights and could not serve as magistrates. They were subject to heavier punishments and much looser standards of evidence in court cases. Clans could be punished for the misdeeds of individual members. The laws were enforced against them by a civic garrison of five thousand men commanded by the Gonfaloniere of Justice. A special magistrate, the Executor of the Ordinances of Justice, was established to deal with magnate offences (4.99).

It is clear that no orthodox Aristotelian could or should have approved of the Ordinances of Justice. Aristotelian institutions in general and Aristotle's ideal mixed polity in particular were designed with a view to neutralizing partisanship. Aristotle's aim is to maximize virtue and wisdom in government and to ensure that governors rule in the interests of all. But everyone needs to see that his interests are being observed, which means allowing each class of persons in the state, rich, middling and poor, some voice in their own rule, some degree of participation in their own 
governance (Politics 6.4). This in turn requires a careful balancing of oligarchic and democratic elements in the design of the constitution. And however the interest of the rich and the poor are balanced, the predominant power in the state should be held by its wisest and most virtuous citizens, whom Aristotle identifies as the men of 'free birth, wealth, culture, and nobility of descent'. 'Quality' should dominate 'quantity', i.e., the nobler sort should dominate the multitude (Politics 4.12). And the state cannot endorse formal injustices to particular classes because this leads only to further strife. Law is defined as reason free from passion (Politics 3.16) and should provide a check on partisanship by remaining a strictly neutral arbiter. Impartiality of the laws is of capital importance and should be characteristic of all constitutions (Politics $3.15)$.

Bruni's praise of the Ordinances, on the other hand, shows that, like Machiavelli, he takes partisanship for granted; he regards it as an inescapable fact of political life. Bruni's History never argues that partisanship can be neutralized in the orthodox Aristotelian way, by a mixture of opposites. ${ }^{16}$ Bruni instead endorses the Florentine solution, to ensure the victory of the best party by legal measures and force. In other words, he admires the Ordinances of Justice precisely because they institutionalize partisanship. They are explicitly designed to ensure that, in any struggle between a popolano and a member of the nobility, the state will back the popolano and enable him to compensate for the superior power of the nobleman. The laws have to be partial to the weak to protect the weak.

Bruni takes the same partisan view of the Guelf and Ghibelline factions. The Guelfs are the party of the papacy, which is valued because (most of the time) it supports the liberty of Italian cities. It is historically the basis of Florentine alliances in Tuscany and elsewhere. The Ghibellines are an unpatriotic party consisting of 
potential traitors, a party which supports the German barbarians who have usurped the name of the empire. The Guelf Party or Parte Guelfa - a semi-public patriotic society charged with neutralizing Ghibelline influence in the city - is praised by Bruni as a moral censor (2.117). Although the Guelf Party is later criticized for a lack of moderation in persecuting Ghibellines, or supposed Ghibellines (8.19-20), Bruni strongly upholds the legitimacy of its role in suppressing pro-imperial partisanship.

So guildsmen need to rule and they need to make use of institutional partisanship - positive discrimination as one might say today - in order to enforce the laws against the nobility. And Guelfs need to be able to suppress Ghibelline power: a state can only have one foreign policy. At the same time, the People cannot do without the wide experience and expert military, diplomatic and legal knowledge of the nobility. Ideally, the nobility and the People should cooperate. Magnates must learn to accept that political office is the exclusive possession of the People. They must learn to be good Florentines and put country ahead of private interests, even though public honours are largely denied them. ${ }^{17}$

Bruni offers in Book XI an example of a great man, Donato Acciaiuoli, who failed to be a good citizen. Acciaiuoli was a member of an extremely wealthy and powerful popolano family and a leading member of the regime. But he also had many friends and clients among the exile communities, nobles and persons accused of Ghibelline sympathies. At the end of 1395, in the middle of Florence's struggle with Milan, he made the mistake of putting the interests of his exile friends above that of the city and began scheming secretly through his agents in the governmment to have them restored to political rights. His scheme was found out and he was summoned before the Priors. Either from a sense of citizenship or from arrogance he did not appear with armed followers, as his friends were urging, and so he was taken captive 
and driven into exile (11.35-6). The following is Bruni's summation of his behaviour. (It is worth keeping in mind that Bruni was composing this book of the History between 1439 and 1442 when serving on the Ten of War along with Donato's descendent Angelo Acciaiuoli and Cosimo de’ Medici.)

It was thought that two things most of all stood in the way of this great man: first, his excessive and unconstrained power, and second, his excessive liberty in censuring others. The former earned him envy, the latter, the ill-will of many men. Ambassadors sent to the city frequented his house, and all who had some business with the city took refuge with him as with a patron. Not even his friends approved of this behavior, and his enemies used to call him, calumniously, 'duke' and 'lord' - so vexing is all preeminence in a free city! His excessive freedom of censure was also an obstacle to him. Himself a man of blameless life, he could not bear vices in other men and often would criticize them. Such censures did not so much help the republic as they injured him; citizens in a free city should be advised and directed in a kindly way, not criticized insultingly. On these grounds Acciaiuoli was expelled and banished, and was deprived of his fatherland. Letters of state were written to his brother, a cardinal of the Roman church, explaining the reason for the banishments. They said the magistrates had driven this leading citizen into exile only with grief and reluctance, because at an extraordinarily difficult moment he had encouraged certain citizens to hope for a renewal of their political rights and restoration; and he had made preparations so that, if he could not obtain what he wanted by public deliberation, he would set about accomplishing it by force of arms (11.37).

The city needs great men but they must learn to behave like citizens. ${ }^{18}$ Yet the People too must learn to defer to the superior expertise of the nobility, especially in military and diplomatic affairs. The state needs the nobility as an 'ornament' at home; they need the wealth of the nobility to embellish the city; they need its guidance in 
matters of taste and letters, but above all they need its advice in peace and war. Bruni demonstrates over and over again how failure to accept good advice from military experts has led to disaster.

This, indeed, is one of Bruni's chief messages of Book II, where the rashness and imprudence of a 'fierce people'; its failure to take the wise advice of illustres viri et rei militaris periti led directly to the greatest military disaster in Florentine history, the battle of Montaperti (2.36-51). 'Plebeians ignorant of the art of war' ('the sort who tend to predominate in magistracies', he adds) were so eager for glory and plunder that they failed to appreciate the overwhelming advantages of the enemy's position and to see through the Ghibellines' disinformation campaign. So, foolishly, they decided to march out and face the enemy. At this point a group of nobiles, led by Tegghiaio d'Aldobrandi de'Adimari, tried to persuade the magistrates of their error, laying out carefully all the advantages and disadvantages of going to warclassic Florentine ragione. But all for nought. After Tegghiaio's speech there arose a popolano magistrate named Spedito, 'the sort of person unrestrained liberty can sometimes produce'.

For some time he had barely been able to contain himself as he listened to this good advice. As soon as Tegghiaio had finished speaking, he shouted - his limbs and voice shaking with passion - 'What are you after Tegghiaio? Have you turned into a filthy coward? This magistracy isn't going to pay any attention to your fears and quakings. It's going to consider the dignity of the Florentine people. If you're paralyzed with fear, we'll let you off military service' (2.48).

Tegghiaio defended himself with dignity, but the die had been cast. 
Then, when the rest of those present fell to grumbling and began to defend their decision, the magistrates fixed a fine for anyone who debated the matter further. The rashness of the magistrates was assisted by a fierce people, proud of its many victories. They wished to march out fearlessly and expose themselves voluntarily to battle, not so much out of concern for their allies' perils, nor led by any particular goal, but simply to avoid the appearance of being afraid of their enemies. The best course having thus been shouted down, the expedition was prepared with resolve (2.50-51).

The result, of course, was the disaster on the Arbia, the return of the Ghibelline exiles and the temporary eclipse of the popolo.

But here again, Bruni's Aristotelianism is less than orthodox. He does not take for granted that virtue is found predominantly among the rich and noble, but assumes that it is fairly widely distributed down the social pyramid. He is even able to praise the virtus et constantia of Michele di Lando, the ringleader of the Ciompi revolt, even though the latter is a homo ex minima plebe. Indeed, he is frankly admiring of Michele's 'natural authority and not ungentlemanly appearance' (auctoritas quaedam nativa et forma viri non illiberalis). ${ }^{19}$ Even though the man was from the lowest of the plebs, even from the working classes (etsi ex infima plebe ex ipsoque opificio prognatum), he nevertheless showed a kind of virtue in restraining the worthless desires and malignant wills of the multitude (9.7-10). It is hard to imagine Plato or Aristotle finding similar words for Cleon, the demagogue of late fifth-century Athens. On the other hand Bruni does not mince words in describing the traitorous and wicked behaviour of much of the nobility. Of course Florentine history provided him with numerous unavoidable examples of bad behaviour on the part of the nobility. But this does not alter the fact that Bruni's beliefs about the distribution of virtue by classes reveal social prejudices quite different from those of Aristotle. His character 
descriptions in the History push against the Aristotelian assumption that nature divides mankind spontaneously into social pyramids, with virtue and wisdom found chiefly at the top among the wealthy and well-born. Bruni himself manifests a prejudice in favour of the optimates on numerous occasions, to be sure, and in his personal life he was as deferential to noble families as any other upwardly-mobile commoner and immigrant. There are numerous instances in the History where Bruni casts an admiring glance upwards at rank and wealth and a contemptuous gaze downwards at 'the dregs' (faex) of Florentine society. Yet from an Aristotelian perspective it is still remarkable the extent to which Bruni is willing to praise the virtue of ordinary, middle-class Florentines and criticize noble behaviour. As far as the success of the Florentine state is concerned, the main usefulness of the nobility is not their moral virtue but their expert knowledge, wealth, and foreign connections, all useful to the state.

For Bruni, in short, the great virtue of the vivere civile is moderation, and it is a principal lesson of the Histories that all classes of citizen need to moderate their behaviour. His prescription for civic harmony has far more to do with the Ciceronian concept of concordia ordinum than with Aristotle's careful apportionment of public powers among economic classes. For Bruni, the nobility need to accept the authority of the People and not attempt to exercise direct power through magistracies. They shouldn't behave like lords and soldiers when participating in civil society. Within the city they need to lay aside their signorial and military characters - appropriate on their country estates and in wartime - and treat other citizens with equality and respect. ${ }^{20}$ They should observe the laws and temper their desire for honour. If revenge is called for, they should seek redress through the courts, not by violence. They should restrain their desire for luxury as it leads to visible inequalities and impoverishes the state. 
The Popolo, on the other hand, needs to defer to the experience, expertise and tried loyalty of meritorious aristocrats and not be carried away by passion. It should not try to persecute the nobility to excess, as that only drives them into the hands of foreign enemies (6.93). It should not abolish proper distinctions for merit out of a misplaced zeal for equality (7.24). It should recognize that the nobility give riputazione to a city and help beautify it. The example to avoid is that of the French, a naturally incivil people whose arrogant nobility treat the common people 'almost like slaves' (6.112).

In sum, Bruni in his Histories often makes use of Aristotelian categories of analysis, but his conclusions and the beliefs that support those conclusions are foreign to Aristotle. Bruni uses Aristotle as a rhetorician would - as Cicero would instrumentally, to strengthen his argument for a non-Aristotelian conclusion: that the historian can judge institutions and patterns of citizen behaviour on the basis of their tendency to promote or inhibit the well-being and glory of the state. This is strikingly different from Aristotle's goal for political life. Although he states explicitly that ethics is a branch of politics and subordinate to it, ultimately Aristotle's state is meant to subserve human flourishing in both the active and contemplative lives. In the end, Aristotle sees a non-political activity, contemplation for its own sake, as the highest human activity. That is why Aristotle condemns any constitution designed with a view to expansion and empire (for example the Spartan), because it falsely privileges the honour-seeking part of our natures above the rational, knowledge-seeking part. In choosing between what Machiavelli would call 'a republic for preservation' and 'a republic for expansion', Aristotle sides with the republic for preservation (or longevity). Bruni resembles Machiavelli in wanting both longevity and expansion for Florence. He does not, to be sure, share Machiavelli's radical view that the rules of 
morality are fundamentally different from the rules of political success. But he does share his instrumentalized analysis of institutions and citizen behaviour patterns.

An example from Book XI will help illustrate the point. The date is 1399, and Giangaleazzo of Milan is tightening the noose around Florence, taking control of one town after another in Tuscany until Florence is surrounded on all sides by enemies. The Florentines had an opportunity to break the chain of antagonists the previous year when the pro-Florentine ruler of Pisa, Gherardo d'Appiano, secretly offers them an alliance, via his representative Giovanni Grassolini, if only the Florentines will pay to send him a large bodyguard to protect his position in Pisa. Since Pisa is traditionally Ghibelline and anti-Florentine, Gherardo is in a weak position. But the Florentines see Gherardo's entreaty as a request to support tyranny, and refuse it. Instead of keeping the negotiations secret, they hold a large public meeting where they conclude it would not be in keeping with the dignity of the Florentine People to buy friendship. As a result, Gherardo, whose position has become untenable, is bribed by Giangaleazzo to abandon the lordship of Pisa to him. The same thing happens when the Perugians offer alliance in return for military support against the pope, who is trying to reassert his lordship over that city. The Florentines refuse because they are too good Guelfs to oppose the pope, but the result is that Giangaleazzo takes control of another neighboring city. Thus the Florentines' misplaced sense of honour, exaggerated respect for the pope, and ideological opposition to tyranny blinds them to their true interests. It leads them foolishly to refuse alliances which would have stopped Giangaleazzo in his tracks.

Bruni lets us know what he thinks of these actions in a speech of the oligarch Rinaldo Gianfigliazzi, another of his heros, before a large political meeting, or practica, in the Palazzo Vecchio (see Appendix). It effectively summarizes Bruni's 
views about the weaknesses of popular governments when engaging in military affairs as well as his ideas about how those weaknesses might be remedied. ${ }^{21}$ What Bruni advocates in this passage is clearly a species of political realism. The existential threat of defeat in war requires that the Florentines place the good of the state first and shelve, at least temporarily, their traditional religious deference to the pope, their constitutional safeguards against overmightly citizens, and their folk prejudices in favor of popular decision-making and public debate of policy. Bruni observes a tendency for popular governments to manifest 'sloth and negligence' and calls for vigor in the executive. Thus Gianfigliazzi advocates constituting a war commission (presumably a Dieci di Balia or Ten of War) consisting of wise and virtuous citizens to take charge of the state's foreign policy, who can act with the swiftness and secrecy required for successful warfare, untrammelled by the usual cumbersome decisionmaking processes of the commune. Not coincidentally, this was a magistracy on which Bruni himself served three times in the period when he was writing the last three books of his History. ${ }^{22}$ Like Machiavelli (Discourses 1.8), Bruni sees the envy of small men as an obstacle to the emergence of great leaders and would like to see steps taken to prevent slander and judicial harassment. Above all, Bruni manifests a respect for armed force and a certain contempt for citizens who always advocate peace, whether from religious or economic motives, and fail to recognize the need for strength in foreign affairs. His preference is for a standing professional army rather than citizen levies. The good citizen should prefer peace but when the state's interests are best preserved by war, he should be ready to support war.

Bruni's prescriptions for civic harmony and for acquiring strength and prestige internationally take him very far from the usual pieties of humanist educational thought, including those contained in his own De studiis et literis. ${ }^{23}$ That work and 
other humanist educational treatises are largely in the Isocratean tradition of cultivating one's abilities and virtues so as to achieve personal honour and distinction. The state benefits indirectly, by possessing virtuous political elites. The humanists' technique for acquiring distinction is study of the classics, which means emulating Roman linguistic and behavioural patterns, on the assumption that the ancients were better, more glorious, more wise, more powerful than the specimens of humanity found in the corrupt modern world. Ancient eloquence and shining examples of ancient virtue would of themselves inspire us to live better lives.

Bruni in the Histories is using a different economy of persuasion. He is urging his fellow-citizens to act with virtue because their history shows that failure to do so leads to collective shame and disaster. (This is perhaps why Bruni's history spends so much more time on Florence's failures than on her successes.) He does not promise that an individual's virtue will be rewarded with a flourishing life in every case - as, indeed, is shown by the fate of his hero, Giano della Bella, who was stripped of his property and expelled from the city by his ungrateful fellow-citizens (4.40). But he does promise that the city whose ruling classes behave with virtue will be free, powerful and glorious. Perhaps they will even prove themselves destined for universal empire, like ancient Rome. But that is the promise of a Roman statesman like Cicero, not a philosopher like Aristotle. And Bruni's mode of analysis, his subordination of private virtue to the glory of the state, and his attempt to establish loyalty to the state above all other loyalties to party, class and even to the Church, shows that his closest kinship as a political thinker is not with Aristotle, Polybius, Thomas Aquinas, nor even with Ptolemy of Lucca, but with Machiavelli. 


\section{APPENDIX}

Speech of Rinaldo Gianfigliazzi Before the Florentine Priors, 1399

From the HISTORY OF THE FLORENTINE PEOPLE, 11.75-78

We must all give you the greatest thanks, most excellent Priors, that, in this most difficult time, when everything is awash in uncertainty and suspicion and dangers manifest themselves on all sides, you have resolved to consult your citizens about the security of the republic. For when magistrates neglect dangers and take no counsel, they generally allow scope for irreparable ruin. I shall give my view faithfully and I ask you to forgive me if I some things I say are said with excessive freedom, for the truth must not always be silent. For my part I confess that the dangers now besetting the city are great, but I am afraid not so much on account of those dangers themselves as on account of our own character. For as long as I can remember I have always seen us, because of our sloth and negligence, feebly losing the opportunity in every enterprise to take provident action. The reason for this evil is that the people and the mob do not look to the future and do not sense dangers until they actually occur; and outstanding men, if there are any among us involved in governing the state, although they may foresee dangers, nevertheless dare not and cannot forestall them. For so great is the freedom to calumniate in this city of ours that no sooner does someone explain the danger and advise taking action against it than many people start shouting that he is a warmonger and can't bear peace, and they hedge him in with malicious laws and tie him up with a thousand difficulties and prohibitions. So even if someone wants to take precautions for the security of the republic, he is left no way to do it! Thus it happens that we flee from opportunities and do nothing. But when dangers are at the doorstep and cannot be avoided, then - finally! - do we become alarmed and take advice, then we summon the Council of Two Hundred and the Council of One Hundred and Thirty together to discuss a matter and a business from which there is no escape. 
I should not be so upset if our struggle was with another popular regime, for then the positions of both parties would be equal, or nearly so. But our present struggle is not with another popular regime but with a tyrant, who is ceaselessly awake to his own interests, does not fear slanderers, is not held back by malicious laws and does not wait upon the decree of the mob or the deliberations of the people. So it is not to be wondered at if he strikes first in conducting his affairs, while we are still pondering remedies when our affairs are already lost. Certain of our citizens took extremely poor advice and rejected the Pisan Giovanni Grassolini when he offered us alliance and confederation with the Pisans, spurning the advice of those who pointed out the danger of that city coming into Giangaleazzo's power. If that danger had been blocked then, we would not be beset with dangers as we are now. Recently, too, certain men took equally bad advice and rejected the Perugian envoys who came to us to inform us of the dangers they were in and asking to join our confederation and alliance. They shouted that the men who thought they should join were trying to start a new war against the pope. The Perugians then turned to Giangaleazzo and have now, I believe, been taken over by him.

Now we are at last starting to think about the danger threatening us from that source. We should blame no one but ourselves; nothing has made the Duke of Milan's power in Tuscany grow more than our own sloth and weakness. But what has been done up to now cannot be changed. In future, however, if you do not rein in calumnies of this sort and excessive license in belittling others and the impediments that stand in the way of quick action, you may expect no remedy for your condition. But if you wish to correct behavior of this sort and take correct counsel from us, there is still good hope that we may preserve, not only our liberty, but our prestige (status) as well. For we do have a large and wealthy city, a wide dominion, many towns besides, a large and strong population and almost innumerable fortified citadels. Our adversary will come to realize that it is a harder matter to crush us than he thinks, if we have the will to act as men and protect the position and the liberty left us by our forebears.

But above all it is necessary to remove now the evils I have just enumerated from the city. Let there be some vigilant persons in the state who 
have the power to act without being compelled to refer every single thing to the multitude and wait upon their decree. State affairs generally require swiftness and secrecy, things which are very much at odds with mass decisionmaking. Let the slanders and indictments of calumniators against great men cease. Let everyone understand the grave perils that threaten them and the great virtue and industry and expense it will require to ward them off. Only after these steps have been taken at home, I think, should we make provision for foreign affairs; let us provide ourselves with soldiers and a captain-general who may stand ready for our expeditions. We shall be more respected by both friends and enemies if they see we have sufficient power about us; if we lack such power, everyone will despise us. This is my general advice. 


\section{NOTES TO 'A MIRROR FOR STATESMEN'}

James Hankins, Department of History, Harvard University, Cambridge, MA 02138. jhankins@fas.harvard.edu.

\footnotetext{
* I am grateful to John Najemy and Eric Nelson for reading this paper and offering corrections and improvements.
}

${ }^{1}$ Gordon Griffiths, James Hankins and David Thompson, eds. The humanism of Leonardo Bruni: selected texts (Binghamton, New York, 1987), pp. 43-44, 52.

${ }^{2}$ Riccardo Fubini, Storiografia dell'umanesimo in Italia da Leonardo Bruni ad Annio da Viterbo (Rome, 2003), pp. 113-15.

${ }^{3}$ James Hankins, Repertorium brunianum: a critical guide to the writings of Leonardo Bruni (Rome, 1997); Leonardo Bruni, Historia universale di messer Lionardo Aretino, tr. Donato Acciaiuoli (Venice, 1476); on Acciaiuoli's translation, see Rosella Bessi, 'Un traduttore al lavoro: Donato Acciaiuoli e l'elaborazione del volgarizzamento delle Historiae', in Paolo Viti, ed., Leonardo Bruni cancelliere della Repubblica di Firenze (Florence, 1990), pp. 321-338.

${ }^{4}$ Eric Cochrane, Historians and historiography in the Italian Renaissance (Chicago 1981), pp. 3-9.

${ }^{5}$ Quentin Skinner, The foundations of modern political thought, (Cambridge 1978), ch. 4; idem, Visions of politics, vol. 2: Renaissance virtues (Cambridge, 2002), pp. 128-35; Antony Black, Political thought in Europe, 1250-1450 (Cambridge, 1992), 129-35; J. H. Burns, ed., The Cambridge history of medieval political thought, ca. 350-1450 (Cambridge, 1988), pp. 605-6; Manlio Pastore Stocchi, 'Il pensiero politico 
degli umanisti', in Luigi Firpo, ed., Storia delle idee politiche, economiche e sociali, (Turin, 1987), pp. 3-68 at 9-17.

${ }^{6}$ Hans Baron, The crisis of the early Italian Renaissance: civic humanism and republican liberty in an age of classicism and tyranny (2 vols., Princeton 1955), I, 5254, 143-144, 324; II, 618-623, 630-32; idem, In search of Florentine civic humanism (2 vols., Princeton, 1988), chs. 3-4; Anna Maria Cabrini, 'Le Historiae del Bruni: risultati e ipotesi di una ricerca sulle fonti', in Viti, ed., Leonardo Bruni cancelliere, pp. 247-319; Fubini, Storiografia, chs. 5-7; Antonio La Penna, 'Il significato di Sallustio nella storiografia e nel pensiero politico di Leonardo Bruni', in idem, Sallustio e la 'rivoluzione romana' (Milan, 1968), pp. 409-31; Emilio Santini, Leonardo Bruni Aretino e i suoi Historiarum Florentini populi libri XII (Pisa 1910); B. L. Ullman, 'Leonardo Bruni and humanist historiography', in B. L. Ullman, Studies in the Italian Renaissance (Rome, 1955), pp. 321-44; Donald Wilcox, The development of Florentine humanist historiography in the fifteenth century (Cambridge, Massachusetts, 1969); Nancy S. Struever, The language of history in the Renaissance: rhetoric and historical consciousness in Florentine humanism (Princeton, 1970).

${ }^{7}$ Nancy Struever's view that Bruni's speeches were rhetorical displays meant to show both sides of an issue has been rightly criticized by Gabriele Pedullà, 'Il divieto di Platone: Niccolò Machiavelli e il discorso dell'anonimo plebeo (Ist. Fior. III, 13)', in Jean-Jacques Marchand e Jean-Claude Zancarini, eds., Storiografia repubblicana fiorentina, 1494-1570 (Florence, 2003), pp. 209-66 at p. 223 (citing Struever, The language of history, p. 129). 
${ }^{8}$ Harvey C. Mansfield, 'Bruni and Machiavelli on civic humanism', in James Hankins, ed., Renaissance civic humanism: reappraisals and reflections (Cambridge, 1999), pp. 223-246 at pp. 230-232.

${ }^{9}$ Griffiths et al., eds., The humanism, pp. 259-62.

${ }^{10}$ Bruni's History will be cited throughout by book and chapter number as in Leonardo Bruni, History of the Florentine People, ed. and tr. James Hankins (3 vols., Cambridge, Massachusetts, 2001-2007). The English translations are taken from the Hankins edition.

${ }^{11}$ Bruni chose not to draw this conclusion when discussing the institution in 1323 of voting by lot - of which he disapproved -, though he admitted that it had lasted down to the present time, 'maintained in the state by a measure of popular favour' (5.81). ${ }^{12}$ For the tension or rivalry between Greek and Roman republican theories in the early modern period, see Eric Nelson, The Greek tradition in republican thought (Cambridge, 2004).

${ }^{13}$ See Carol Lansing, The Florentine magnates: lineage and faction in a medieval commune (Princeton, 1991).

${ }^{14}$ For the incivility of the French as a people see Bruni's remarks in his De militia, discussed in James Hankins, 'Civic knighthood in the early Renaissance: Leonardo Bruni’s De militia (1420)', Renaissance Quarterly (forthcoming). Bruni's novel Antioco, meant to be a critique of Boccaccio's Novella di Tancredi (Decameron 4.1), was also directed against chivalric values, especially the folly of romantic love; see idem, 'Humanism in the vernacular: the case of Leonardo Bruni', in Humanism and creativity in the Renaissance: essays in honor of Ronald G. Witt (Leiden-Boston, 2006), pp. 11-29 at 16-17. 
${ }^{15}$ Leonardo Bruni, Opere letterarie e politiche, ed. Paolo Viti (Turin, 1997), pp. 78486. The work was written for Greek visitors attending the Council of Florence in 1439.

${ }^{16}$ In his Constitution of the Florentines Bruni states the Florence's constitution has a mixture of democratic and oligarchic elements, though power remains predominantly in the hands of the oligarchy; see Bruni, Opere, pp. 776, 784.

${ }^{17}$ Bruni does approve the practice of awarding 'ornamental' offices to magnates such as ambassadorships and civic knighthoods. But he insists that the nobility should never have other than an advisory role in making policy. An example of a nobleman behaving with appropriate moderation, patriotism and deference to popular power is given in the Pisan noble Franceschino Gambacurta (7.70-75), who lays aside his feudal obligations to the archbishop of Milan in order to oppose his tyrannical designs on Pisa.

18 Bruni comes to similar conclusions in summing up the mistakes of another great man, Corso Donati, at 4.104.

${ }^{19}$ It is worth remarking that liberalitas, nobility of character and education, is the humanist substitute for ascribed nobility or nobility of descent.

${ }^{20}$ See Hankins, Civic knighthood, passim.

${ }^{21}$ Florence, Archivio di Stato, Archivio della Repubblica, Consulte e practiche vol. 34, which preserves the political debates of the Signoria and its advisers for the period, reports no speech of Rinaldo Gianfigliazzo on which Bruni’s imaginary oration might notionally be based, though many of the views expressed are broadly consistent with Rinaldo's statements and those of other members of the optimate regime as they are preserved in the documents. See the documentation for the period cited in Bruni, History, vol. 3, 'Notes to the Translation', Book XI. 
${ }^{22}$ See Memoirs $§ 110-118$, in Bruni, History, vol. 3. Bruni's three terms on the Ten began on 1 June 1439, 1 June 1440, and 1 June 1441; the last three books of his History were written between February of 1439 and January of 1442. For the chronology of Bruni's History and Memoirs, see James Hankins, 'The dates of Leonardo Bruni's later works (1437-1443),' Studi medievali e umanistici 5 (2007), forthcoming.

${ }^{23}$ Bruni, Opere, pp. 243-279. For humanist views about the purpose of education, see Humanist educational treatises, ed. Craig W. Kallendorf (Cambridge, Massachusetts, 2002). 